\title{
PERFORMANCE OF THE 3 BLADES HORIZONTAL SAVONIUS WATER WHEEL WITH VARIATION OF ANGLE DEFLECTOR
}

\author{
Daniel Wibowo $^{1)}$, Dwiseno Wihadi' ${ }^{2)}$, Martanto ${ }^{3)}$, Tjendro, Ronny A. ${ }^{4)}$ \\ Jurusan Teknik Mesin, Fakultas Sains dan Teknologi, Universitas Sanata Dharma \\ Jl. Paingan, Maguwoharjo, Depok, Krodan, Maguwoharjo, Kec. Depok, Kabupaten Sleman, \\ Daerah Istimewa Yogyakarta 55281 \\ Email: ${ }^{1}$ danielsongkleng97@gmail.com
}

\begin{abstract}
Abstarct
In Indonesia the needs toward energy has been increasing. Therefore, eco-friendly renewable energy becomes an alternative power source. In relation to the idea, within the conduct of the experimental study the researcher designed a Savonius-type waterwheel with horizontal axis and the waterwheel was tested in the river stream. Then, within the design the researcher applied one waterflow regulator with the angle variation $30^{\circ}, 45^{\circ}$ and $60^{\circ}$. The study was conducted on river flow with a flow velocity of $\pm 0.6 \mathrm{~m} / \mathrm{s}$. the result is the addition of the deflector angle affects the ability to support the load, the maximum wheel efficiency (Cp) of 0.57.
\end{abstract}

Keywords: Savonius, waterwheel, $C p$

\section{Pendahuluan}

Sebagai negara berkembang, kebutuhan akan energi di Indonesia semakin meningkat. Kebutuhan listrik di Indonesia diperkirakan dapat tumbuh rata-rata 6,0\% per tahun hingga tahun 2020 (Outlook Energi Indonesia 2018), maka pemanfaatan sumber energi terbarukan sebagai pembangkit listrik harus dikembangkan. Sebagaimana yang telah diketahui bahwa persediaan sumber energi minyak bumi, gas alam dan batu bara sangat terbatas, apabila secara terus menerus digunakan maka suatu saat sumber energi tersebut akan habis dan diperlukan waktu yang cukup lama supaya alam dapat kembali menyediakan energi fosil tersebut, di samping itu juga kecenderungan melonjaknya harga sumber energi tersebut [1].

Indonesia sebenarnya banyak memiliki sumber energi terbarukan yang dapat dimanfaatkan sebagai penghasil energi listrik [2], contohnya seperti energi surya, energi air, energi panas bumi dan lainnya. Selain untuk memenuhi kebutuhan energi listrik pemanfaatan energi tersebut lestari dan lebih ramah lingkungan dibandingkan dengan energi fosil. Secara nasional, ketersediaan air di Indonesia mencapai 694 milyar meter kubik per tahun yang dapat dimanfaatkan. Namun faktanya saat ini baru sekitar 23 persen yang telah dimanfaatkan. Dari 23 persen tersebut hanya sekitar 20 persen yang dimanfaatkan untuk memenuhi kebutuhan kebutuhan kota dan industri, selebihnya 80 persen dimanfaatkan untuk memenuhi kebutuhan irigasi [3].

Oleh karena itu, energi terbarukan yang ramah lingkungan menjadi pilihan. Potensi air sebagai sumber energi terutama digunakan sebagai penyedia energi listrik melalui pembangkit listrik tenaga air, mikrohidro, maupun pikohidro. Pemanfaatan energi air pada dasarnya adalah pemanfaatan energi potensial dan atau kinetik. Energi mekanik pada aliran air merupakan transformasi dari energi potensial (kinetik) yang dimanfaatkan untuk menggerakan turbin atau kincir [4]. Secara umum, kincir atau turbin air dapat diterapkan pada aliran air manapun dengan volume cukup. Melalui aliran air yang bebas dari sungai, danau dan saluran irigasi dapat di jadikan sumber energi terbarukan yang memiliki potensi cukup untuk dapat menghasilkan energi listrik. 
Kincir air yang umum digunakan adalah kincir air jenis Savonius. Kincir ini menjadi pilihan karena dengan luas aliran yang sempit dan kecepatan aliran yang rendah pun mampu menghasilkan energi [5], dan kincir ini dapat bekerja tanpa bantuan tenaga dari luar. Selain itu kincir ini memiliki disain yang sederhana dan murah untuk di produksi $[6,7,8]$.

Penelitian ini pada dasarnya mengacu pada penelitian yang dilakukan oleh Prawira. Dalam penelitian digunakan kincir air Savonius sudu dua dengan poros horizontal dengan konfigurasi sudut pengarah aliran air $30^{\circ}, 45^{\circ}$ dan $60^{\circ}$. Hasil penelitian tersebut menunjukkan peningkatan daya output terjadi pada sudut $45^{\circ}$ dan $60^{\circ}$. Jadi, peneliti mencoba menggunakan kincir air Savonius sudu tiga dengan poros horizontal konfigurasi sudut pengarah aliran air yang sama sehingga mudah membandingkan daya output antara referensi dan yang dilakukan oleh peneliti.

\section{Metodologi Penelitian}

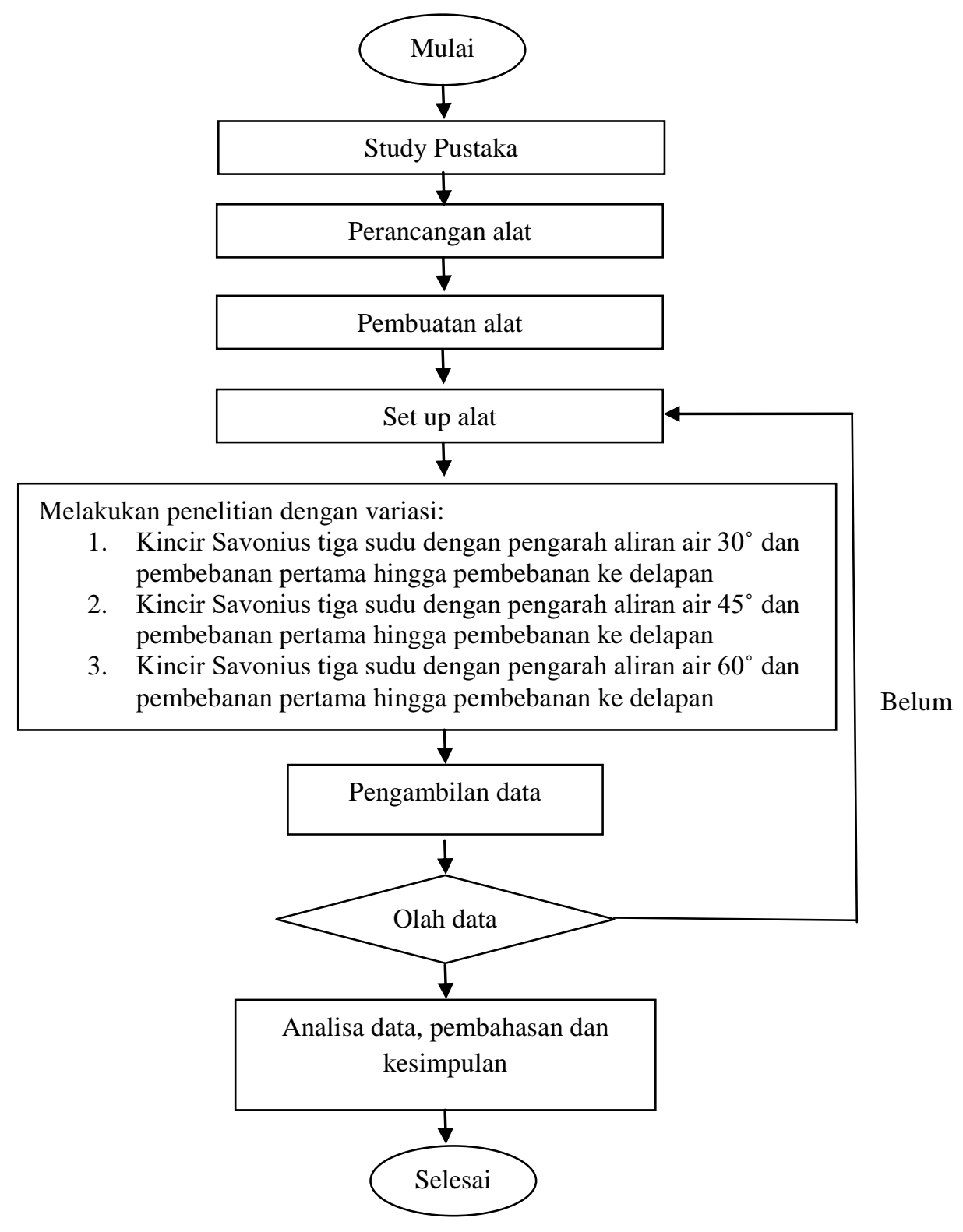

Gambar 1. Diagram Alir Penelitian 
Pada penelitian ini, metode yang dipakai adalah metode eksperimen. Eksperimen ini akan dilakukan dengan membuat alat berupa kincir air tipe Savonius dengan poros horizontal yang nantinya diuji coba pada aliran sungai. Penelitian dilakukan pada aliran sungai yang dianggap stabil dengan kecepatan aliran $\pm 0,6 \mathrm{~m} / \mathrm{s}$ dengan menggunakan peralatan seperti terlihat pada Gambar 2. Tujuan penelitian ini adalah untuk mengetahui apakah penggunaan sudut pengarah aliran air yang berbeda pada kincir air savonius akan menghasilkan perbedaan dalam hasil pada output daya. Dan proses persiapan materi hingga pengerjaan alat dan bahan dapat diketahui dengan menggunakan diagram alur dibawah ini (Gambar 1).

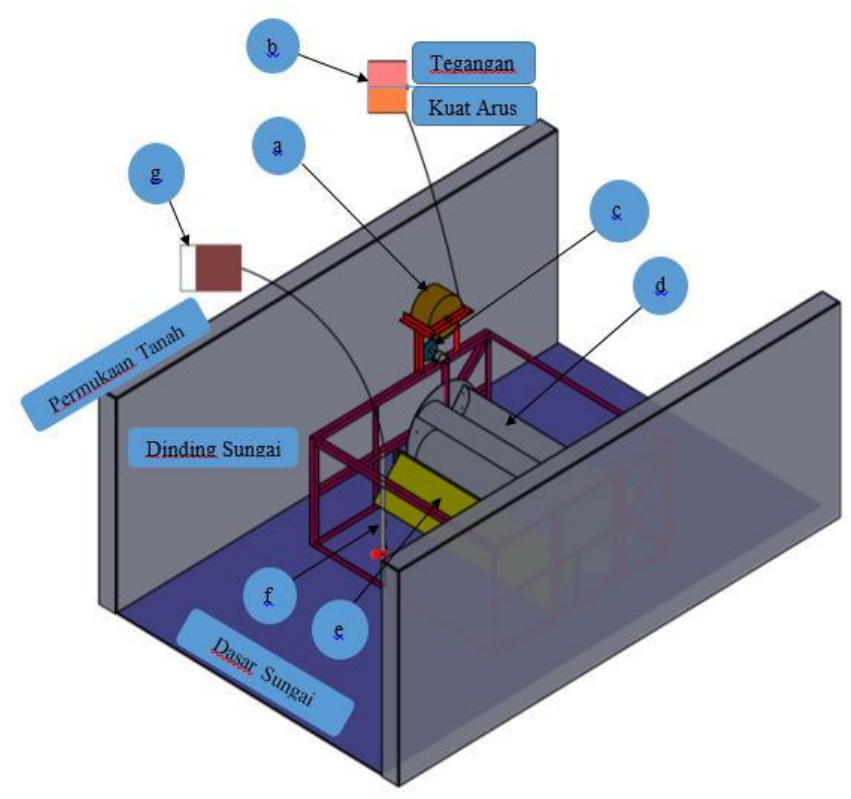

Gambar 2. Skema kincir air Savonius

Keterangan :
a. Generator b. Multimeter
c.Transmisi d.Sudu kincir
e. Deflektor f. Tongkat ukur
g. Current meter

Materi yang dipelajari adalah pengaruh pengarah aliran air terhadap performa kincir air Savonius [4]. Pengarah aliran air yang digunakan hanya 1 buah, yaitu pengarah aliran air pada bagian bawah kerangka kincir dengan variasi sudut $30^{\circ}, 45^{\circ}$ dan $60^{\circ}$ (Gambar 3 ). 


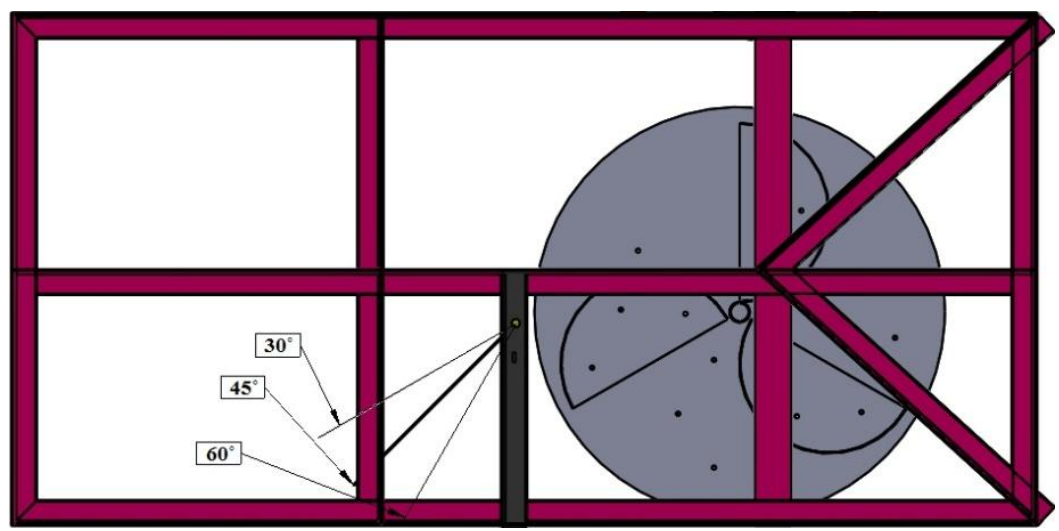

Gambar 3 : Rancangan Sudut Pengarah Aliran Air

Data yang diperoleh dari hasil pengujian kincir air Savonius selanjutnya diolah dan dianalisa. Adapun data-data yang akan diolah dan dianalisa yaitu sebagai berikut:

\section{a. Tip Speed Ratio $(\lambda)$}

Tip Speed Ratio $(\lambda)$ atau TSR pada kincir air adalah rasio antara kecepatan rotasi pada ujung sudu dan kecepatan aktual dari aliran air yang akan kemudian berpengaruh terhadap kecepatan putar rotor (Hayashi et al., 2005). Tip Speed Ratio $\lambda$ atau TSR dengan menggunakan untuk diameter rotor dapat didefinisikan sebagai berikut:

$$
T S R=\frac{\omega D}{2 U}
$$

Keterangan :

$\mathrm{U}=$ Kecepatan aliran fluida

$\omega=$ Kecepatan sudut kincir

b. Daya air

Daya air adalah daya yang terdapat dalam aliran air yang dapat memutar kincir air.

Daya air dapat dicari dengan persamaan :

$$
P a=0,5 \rho A U^{3}
$$

\section{Keterangan :}

$\rho \quad=$ Masa jenis air

c. Torsi

Menurut (Prawira, Y. E, 2019), rumus untuk mendapatkan torsi dapat diketahui dengan persamaan :

$$
T=\frac{P e}{\omega}
$$

Keterangan :

$P e=$ Daya yang dihasilkan

$\mathrm{r} \quad=$ Kecepatan sudut kincir 
d. Koefisien Torsi (Cm)

Koefisien torsi adalah perbandingan antar nilai torsi pada kincir dengan nilai torsi yang terkandung pada aliran air yang menabrak kincir.

Nilai koefisien torsi dapat dirumuskan sebagai berikut :

g. Koefisien Daya (Cp)

$$
C m=\frac{T}{\frac{1}{4} \rho A_{s} D U^{3}}
$$

Koefisien daya adalah nilai perbandingan antara daya yang dihasilkan oleh kincir air dengan daya yang dimiliki oleh air yang melewati kincir tersebut.

$$
C p=\frac{P e}{P a}
$$

\section{Hasil dan Pembahasan}

Hasil perhitungan dan pembahasan dalam penelitian mengenai varian pengaruh kincir air Savonius tiga sudu dengan pemasangan pengarah aliran air $30^{\circ}, 45^{\circ}, 60^{\circ}$ pada aliran sungai dengan kecepatan aliran sekitar $0,6 \mathrm{~m} / \mathrm{s}$. Selanjutnya data tersebut diolah untuk didapatkan grafik perbandingan dari berbagai variasi sudut pengarah aliran air grafik Gambar 3 hingga Gambar 6 sebagai berikut.

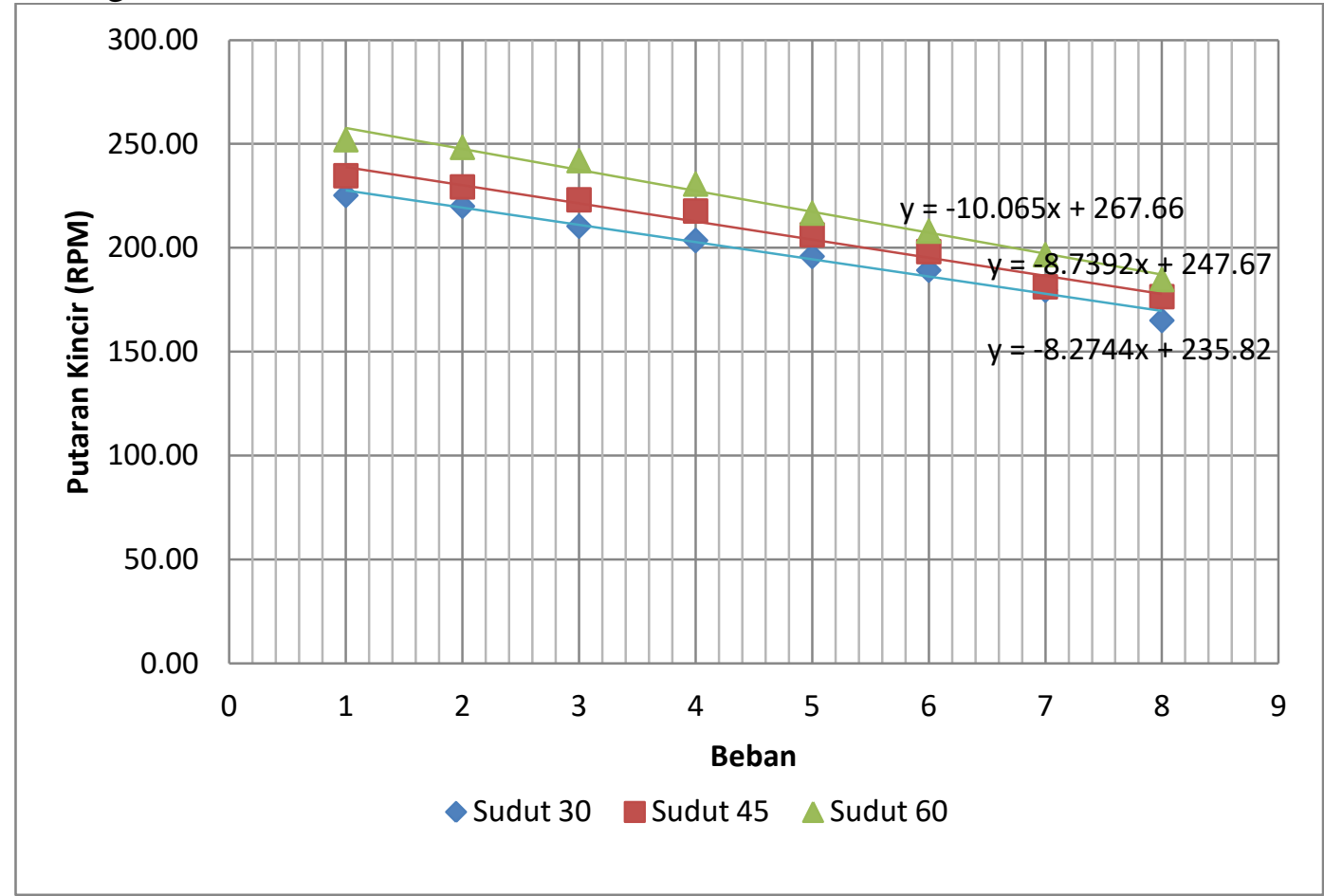

Gambar 3. Grafik hubungan pembebanan terhadap kecepatan putar kincir pada 3 variasi pengarah aliran air

Pada Gambar 3 di atas, diketahui bahwa pembebanan lampu berpengaruh terhadap kecepatan poros. Terlihat bahwa kecepatan poros kincir akan mengalami penurunan apabila diberi beban. Hal ini disebabkan pemberian beban akan meningkatkan gaya lawan pada generator yang selanjutnya ditrasmisikan ke kincir. Pembebanan ini akan membuat poros kincir seperti mengalami pengereman sehingga kecepatan putar poros semakin lama akan menurun. 
Pada gambar tersebut di atas didapati kecepatan putar kincir pada sudut pengarah aliran air $60^{\circ}$ memiliki nilai yang lebih tinggi dibandingkan sudut yang lainnya. Akan tetapi pada sudut pengarah aliran air $60^{\circ}$ memiliki nilai gradien lebih kecil, dengan kata lain penambahan beban lebih berpengaruh terhadap penurunan nilai putaran kincir.

Dalam grafik di atas juga terlihat bahwa kecepatan poros dengan sudut pengarah aliran air $60^{\circ}$ mempunyai nilai yang lebih tinggi dibanding dengan variasi lainnya. Sesuai dengan hasil penelitian Prawira, hal ini karena penggunaan sudut $60^{\circ}$ dapat lebih menutupi bagian cembung kincir sehingga dorongan air yang mengarah ke sisi cekung lebih besar dibandingkan 2 variasi lainnya [9,10]. Nilai putaran tertinggi pada sudut $60^{\circ}$ adalah 35,00 rpm, sedangkan pada sudut $45^{\circ}$ memiliki nilai putaran tertinggi sebesar 32,59 rpm dan pada sudut $30^{\circ}$ memiliki putaran tertinggi sebesar $31,28 \mathrm{rpm}$. Nilai ketiganya berada pada pembebanan lampu pertama.

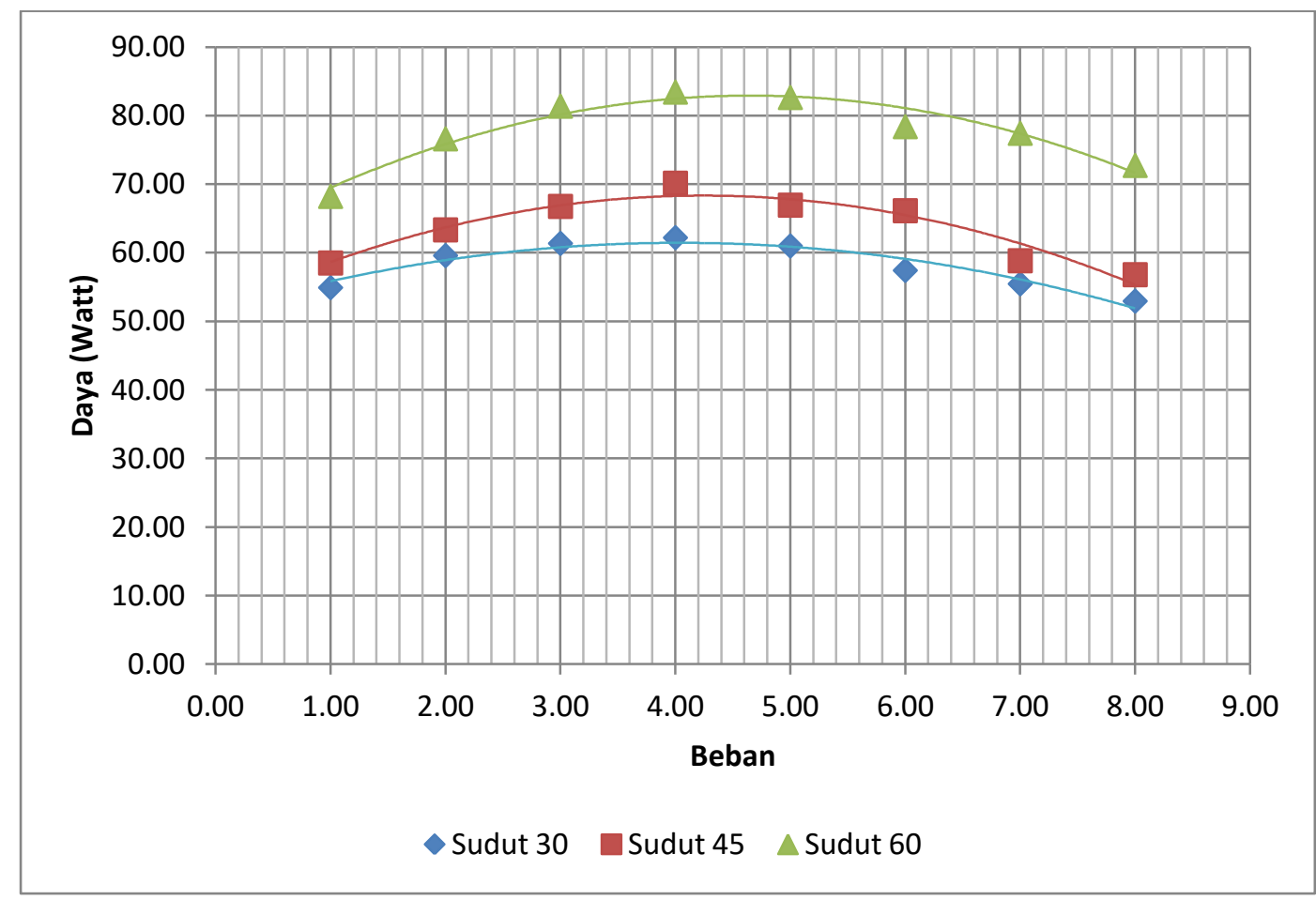

Gambar 4. Grafik hubungan pembebanan terhadap daya listrik pada 3 variasi pengarah aliran air

Pada Gambar 4 di atas terlihat bahwa penggunaan pengarah aliran air dapat mempengaruhi daya yang dihasilkan kincir. Nilai daya tertinggi terdapat pada kincir dengan sudut pengarah aliran air $60^{\circ}$ yang sebesar 83,43 Watt pada pembebanan keempat. Pada kincir dengan sudut pengarah $45^{\circ}$ daya listrik tertinggi sebesar 70,15 Watt pada beban ke empat, sedangkan pada sudut pengarah $30^{\circ}$ nilai daya tertinggi sebesar 62,21 Watt pada pembebanan kedua. Hal ini disebabkan pengarah dengan sudut $60^{\circ}$ mampu mengarahkan dorongan air ke kincir yang lebih besar. Kemiringan tersebut dapat menghindarkan sisi cembung sirip dari dorongan air, sehingga mengurangi rugi-rugi yang mungkin terjadi.

Dalam penggunaan konfigurasi sudut deflektor yang lebih tinggi antara $30^{\circ}$ hingga $60^{\circ}$ akan menghasilkan dayaoutput yang lebih tinggi, peningkatan daya yang terjadi dari sudut $30^{\circ}$ ke sudut $45^{\circ}$ sebesar $12 \%$ sementara meningkatnya daya dari sudut $45^{\circ}$ ke sudut $60^{\circ}$ sebesar $18 \%$. 


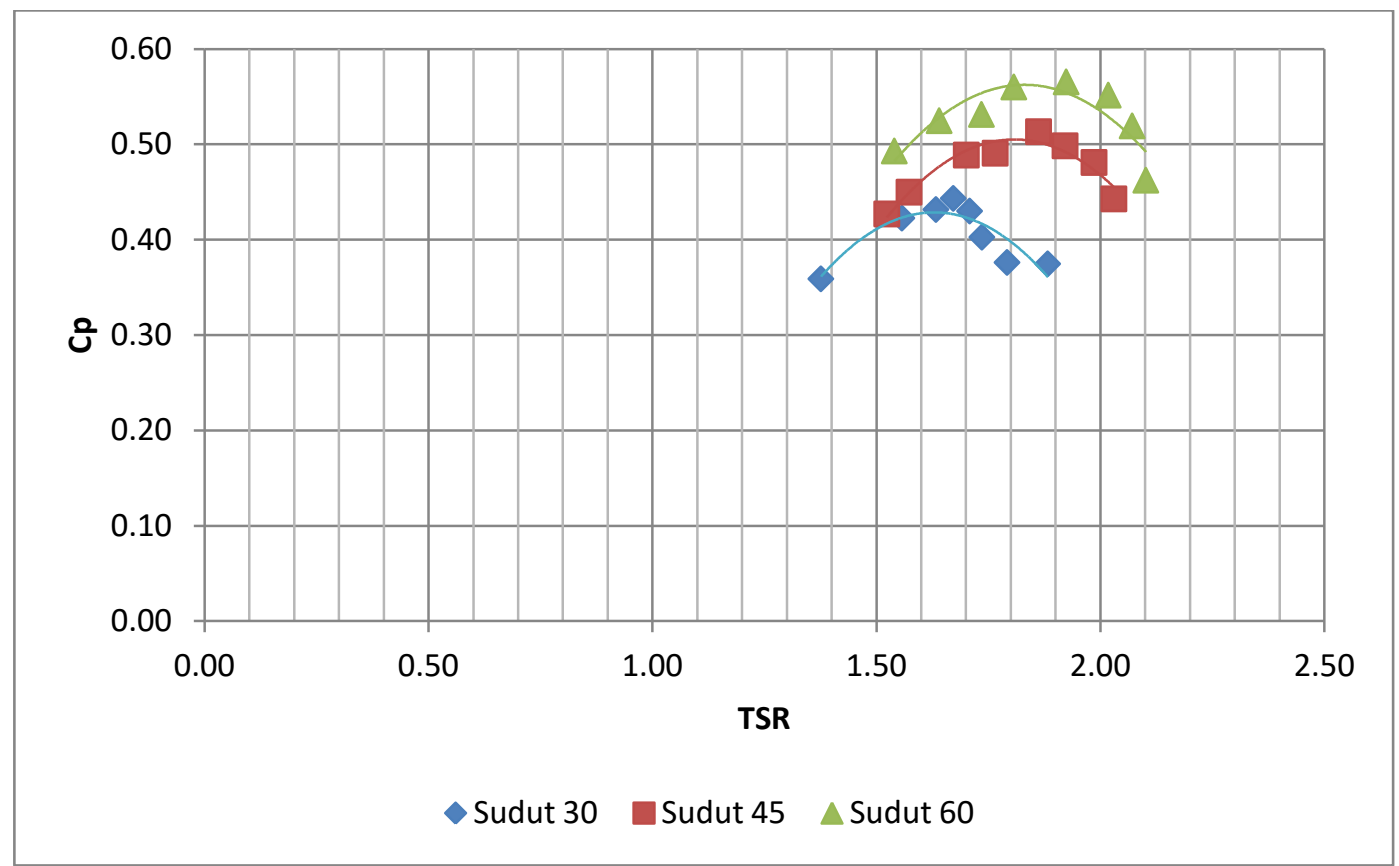

Gambar 5. Grafik hubungan Tip Speed Ratio (TSR) terhadap koefisien daya pada 3 variasi pengarah aliran air

Pada Gambar 5 di atas menunjukan bahwa penggunaan pengarah aliran air dapat mempengaruhi besarnya nilai koefisien daya yang dihasilkan. Dapat dilihat pada grafik tersebut bahwa dengan adanya kenaikan nilai sudut pengarah akan meningkatkan nilai $\mathrm{Cp}$ kincir. Nilai Cp tertinggi diperoleh pada variasi sudut pengarah $60^{\circ}$ dengan nilai sebesar 0,57 pada TSR 1,92. Pada sudut pengarah $45^{\circ}$ diperoleh nilai Cp tertinggi sebesar 0,51 pada TSR 1,86 dan pada variasi sudut pengarah $30^{\circ}$ diperoleh $\mathrm{Cp}$ tertinggi sebesar 0,44 pada TSR 1,67.

Meskipun kincir dengan pengarah $30^{\circ}$ memiliki efisiensi paling rendah, tetapi mampu menghasilkan daya pada TSR paling rendah dibandingkan sudut pengarah yang lain. Hal tersebut mengindikasikan bahwa kincir masih dapat bekerja pada putaran yang lebih rendah.

Membandingkan apa yang telah dilakukan oleh Prawira dengan kincir air Savonius sudu dua, hasil penelitiannya menujukan adanya peningkatan daya pada setiap sudut pengarah antara $10 \%$ hingga $16 \%$, dengan daya listrik tertinggi sebesar 106,24 Watt dengan $\mathrm{Cp}_{\max }=$ 0,701 . Peneliti mendapatkan peningkatan daya antara $12 \%$ hingga $18 \%$, dengan daya listrik tertinggi sebesar 70,15 Watt pada $\mathrm{Cp}_{\max }=0,57$. Didapati bahwa kincir air Savonius sudu dua menghasilkan daya yang lebih besar dan lebih efisien dibandingkan dengan kincir air Savonius sudu tiga.

\section{Kesimpulan}

Berdasarkan penelitian mengenai kincir air Savonius yang telah dilakukan dapat diperoleh kesimpulan sebagai berikut:

1. Penambahan sudut pengarah membuat kincir lebih sensitif terhadap penambahan beban

2. Pada penggunaan sudut pengarah $30^{\circ}, 45^{\circ}$ dan $60^{\circ}$ pada kincir Savonius poros horisontal, efisiensi $(\mathrm{Cp})$ tertinggi diperoleh pada sudut pengarah $60^{\circ}$ dengan nilai sebesar 0,57 


\section{Ucapan Terimakasih}

Peneliti mengucapkan terima kasih kepada Kemenristek Dikti, seluruh dosen dan staff pengajar jurusan Teknik Mesin yang telah memberikan dukungan dan pendampingan sehingga penelitian ini dapat terlaksana. Kepada seluruh keluarga Jogja atas bantuan dan kerjasamanya selama kuliah di Yogyakarta, dan keluarga kandung yang telah membantu dengan memberikan segalanya demi kelancaran penelitian ini.

\section{Daftar Pustaka}

[1] Abadi, R. P (2018). Kincir Poros Vertikal Tipe Savonius Dua dengan Menggunakan Deflektor. Skripsi. Yogyakarta : Universitas Sanata Dharma.

[2] Supandi, S., Padang, Y. A, \& Nurpatria, N. (2018). Unjuk Kerja PLTMH Menggunakan Turbin Savonius dengan Variasi Sudut Deflektor. DINAMIKA TEKNIK MESIN.

[3] Samekto, C. dan Sofia, E. (2016). Potensi Sumber Daya Air di Indonesia.

[4] Purnama, A. C., Hantoro, R. and Nugroho, G. (2013). Rancang Bangun Turbin Air Sungai Poros Vertikal Tipe Savonius dengan Menggunakan Pemandu Arah Aliran. Jurnal Teknik ITS.

[5] Anugerah, Y. (2019). Ujuk Kerja Kincir Air Savonius Poros Horizontal Empat Sudu dengan Variasi Sudut Deflektor. Skripsi. Yogyakarta : Universitas Sanata Dharma.

[6] Prawira, Y. P. (2019). Unjuk Kerja Kincir Air Savonius Dua Sudu dengan Variasi Tiga Sudut Deflektor. Skripsi. Yogyakarta : Universitas Sanata Dharma

[7] Prasetyo, A., Kristiawan, B., Danardono, D., \& Hadi, S. (2018). The Effect of Deflector Angle in Savonius Water Turbine with Horizontal Axis on the Power Output of Water Flow in Pipe. The 2nd International on Journal of Physics: Conference Series 979 012043

[8] Golecha, Kailash. (2011). Study on the Interaction between Two Hydrokinetic Savonius Turbines. India : Indian Institute of Technology

[9] Kailash, G., Eldho, T. I. and Prabu, S. V (2012) Performance Study of Modified Savonius Water Turbine with Two Deflector Plates. India

[10] Prawira, Y. P. dan Wihadi, R. B. D. (2019). Performance of Horizontal Axis Savonius Water Turbine Using Deflector Angle Variations. Sanata Dharma University Yogyakarta 